\title{
Time-space differences of population ageing in Europe
}

\author{
Marcela KÁČEROVÁ, JANA ONDAČKOVÁ and JozeF MLÁDEK ${ }^{1}$
}

\begin{abstract}
Age structure is one of the most important demographic characteristics of the population, which is multicausally related to almost all population processes. On one hand, age structure is the complex result of processes such as fertility, mortality, immigration and emigration. At the same time, it substantially affects a number of socio-demographic phenomena such as marriage, divorce, migration, potential labour resources etc. Certain relationships between the age structure and other population characteristics, such as ethnic, educational, sex, economic or religious structure can also be observed. The demographic behaviour of the European population in the second half of the $20^{\text {th }}$ and the beginning of the $21^{\text {st }}$ century is characterised by significant changes. They are reflected in a number of population processes and indicies, which are typically interconnected and interrelated. These changes have been most strikingly manifested in a drop of fertility rates, changes in family behaviour, and shifts in the age structure of the population. The main aim of this paper is to analyse the time-space development of the age structure of the European population. The period of investigation is 1950-2010 which is extended by a projected development until 2060. Changes in age structure are analysed through several indicators such as coefficients of inflow, outflow and exchange, as well as with indices of economic and social support. Authors make also efforts to provide a complex assessment on population ageing. Using the method of standardised variable, 11 indicators of age structures for 39 European countries are used in the synthesis. In view of the londer time span, several types of age structures are pointed out in Europe.
\end{abstract}

Keywords: population ageing, coefficients of inflow, outflow and exchange, indices of economic and social support, age structure typology

\section{Introduction}

The age structure of population and its development can be considered as a highly complex demographic phenomenon. From the point of view of time, age composition is the result of long-term processes. The complexity of the age structure of

${ }^{1}$ Department of Human Geography and Demography, Faculty of Natural Sciences, Comenius University in Bratislava, 84215 Mlynská dolina 1, Bratislava, Slovak Republic. E-mails: kacerova@fns.uniba.sk, ondackova@gmail.com, mladek@fns.uniba.sk 
population is also demonstrated in its multi-causal relationships with a number of population and social phenomena. The current age structure reflects the longterm evolution of different processes, e.g. natality, mortality and migration.

One of the most typical processes of population development in European countries is population ageing (population rejuvenation is much less frequent). Changes in the age structure have not only relevant demographic consequences and attract the attention of scientists, but they also represent an important social phenomenon. Ageing implies the need to deal with a whole range of social problems that are currently topical mainly in the more developed countries.

The first group of problems is economic by nature, and relates to the balance of active/inactive population. With the increasing proportion of inactive population, it is more and more difficult to cover their pensions. Therefore, it seems to be necessary to create favourable conditions for the further use of their knowledge and workforce (active ageing). Another group of problems is related to the increasing demand for social and medical services by elderly people. As life expectancy is steadily increasing, the share of elderly is rising as well, and their requirements for social services and healthcare are also growing. Special demand of elderly towards housing, transportation, and other services is also well documented.

A seemingly simple assessment of young and elderly population is in fact more complicated due to their mutual relationship, as well as their relation to other age groups. Some authors consider population ageing as the most burning issue of the current population development, in particular in the economically more developed countries. This is because the impact of ageing on the socio-economic and welfare systems of countries (e.g. public pension, healthcare) has been permanently growing (LANZIERI, G. 2011).

The main aim of this paper is to analyse the time-space changes of the age structure of the European population. The period of investigation is 1950-2010 which is extended by a projected development until 2060. Changes in the age composition will be analysed through several indicators such as coefficients of inflow, outflow and exchange, as well as with indices of economic and social support.

\section{Theoretical context and methodology}

From a demographic point of view population ageing is understood as a process, where the number (or share) of population of older age groups is increasing (top-down ageing). This also implies a decrease in the number (or share) of children (bottom-up ageing). The term 'ageing from the middle' is used by MacKellar, F.L. (2003) for the shift of numerous years of the babyboom cohort in the middle of the pyramid (i.e. the 55-year-olds) into the age group of elderly population. 
Population ageing is one of the most typical features of the second demographic transition (VAn de KaA, D.J. 1987; Pastor, K. 1998; MládeK, J. 1998). The ageing process reflects a decrease in fertility, and also improving mortality rates. JACKSON, N. (2001) offers an interesting view of ageing, distinguishing between two technical dimensions: structural and numerical ageing. On one hand, structural ageing is mainly the result of a decrease in fertility. A decrease in the mortality of children and an increase in life expectancy result in a higher number and higher share of elderly population. On the other hand, numerical ageing is originally caused by a drop in mortality.

If child mortality is decreasing, most children survive, causing acceleration of population growth. In the course of several decades, these children reach reproductive age, causing further acceleration of population growth. Both of them cause an initial rejuvenation of the age structure. If the life expectancy of the adult population, those who have survived childhood are more likely to live until old and very old age. High fertility during the baby-boom years will shortly become a contributing factor to numerical ageing, while this need not be the dominant cause. The population will not see a significant increase in the number of elderly people, if mortality is high and even if fertility is very high.

The question about the impact of individual demographic processes on changes in the population age structure is becoming topical. Natality, mortality, immigration and emigration are the processes that basically influence the age structure of population.

Since it is the birth rate that primarily determines the number of people in individual generations, this can be considered the one of the decisive factors. With a decreasing number of born children, bottom-up ageing occurs as well as relative top-down ageing. On the contrary, with increasing numbers of born children, the population gets younger. Similarly, death rate may lead to both population rejuvenation and ageing, therefore this is another important factor. If mortality in young age groups is decreasing (newborn, infant, child mortality etc.), the population gets primarily younger. If mortality in higher age groups is decreasing, the population gets older.

The third factor which might affect the age structure of population is migration. Since population of productive age tends to migrate most frequently emigration causes normally population ageing. In contrast, immigration increases the proportion of productive population and results in rejuvenation of the age structure.

However, the effect of these processes does not only depend on the intensity itself, but also on the age structure of the population in which the processes take place (e.g. the number of born children depends not only on the birth rate intensity, but also on the number of women of fertile age). In addition, their effects may multiply or be partially eliminated, so the age structure may be 


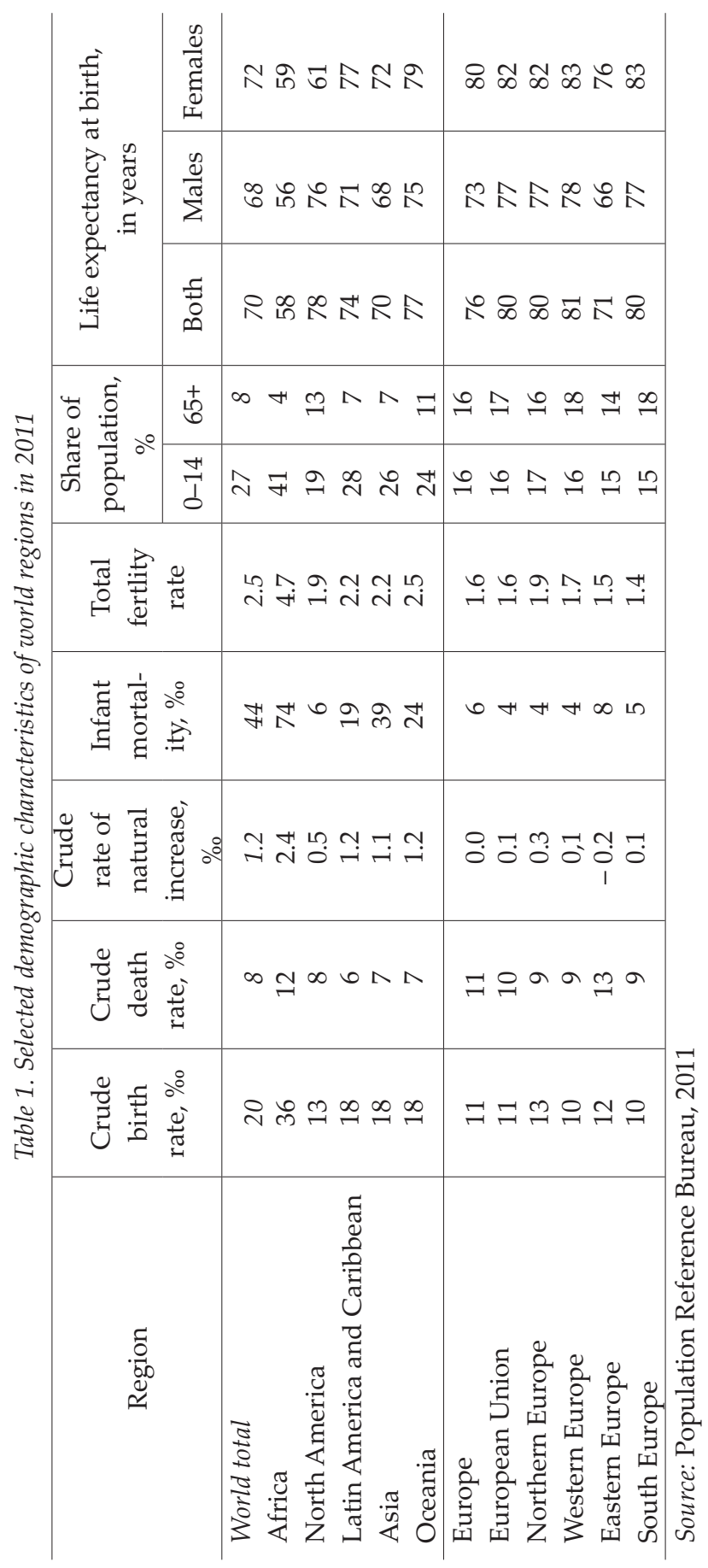

formed very differently in each population as a result of the abovementioned processes.

\section{The age structure of European population from a global perspective}

Changes in the age structure have spatial implications. They are manifested at all geographical levels, from the lowest municipal level, to regions, countries, and the global level. On the level of continents, age structure and ageing has specific features (Table 1).

The ageing of population is most pronounced among the continents in Europe (738 million people), mainly as a result of a drop in the total fertility (1.6) rates. In 2011 the share of children was equal with the share of people aged 65+ with $16 \%$ each. The ratio of people aged $65+$ has doubled since the mid$20^{\text {th }}$ century. The most dynamic growth can be seen in the population group $80+$, where the 1950 share $(4.1 \%)$ in- 
creased by 3.7 times by now. The European population has a high median age -40 years; it has a high life expectancy at birth (73 for men and 80 for women). The forecast (UN 2011) points out this ageing trend, mainly at the top of the pyramid, where the share of the population aged $65+$ will increase to $27.6 \%$. Ageing of the senior population itself requires special attention. On the global level, the pace of ageing is considered to be the most dynamic in Europe.

On the regaional level we can see certain differences in population ageing. Two large regions - Northern and Western Europe - currently have similarly low level of infant mortality rates, higher rates of total fertility, and higher proportions of elderly population. In contrast, Eastern and Southern Europe have a slightly higher infant mortality rate, and lower rates of total fertility, and lower proportions of children.

In terms of ageing Europe is followed by North America which has similar demographic features. The level of ageing is very similar in three global geographical units - Asia, Latin America and Oceania - although there are certain differences among them. The lowest infant mortality rate is recorded in North America; whereas the highest share of the post-productive group and also the highest level of life expectancy is recorded in North America and Oceania. Highest infant mortality rate and lowest life expectancy at birth is recorded in Africa.

\section{Development and regional differentiation of ageing within Europe}

In the mid- $20^{\text {th }}$ century Europe had a relatively young population. However, dramatic ageing process has taken place over the last 60 years, and it is expected to continue. In the current stage of demographic evolution of most European countries, we may speak about an alarming level of population ageing. Based on the processes shown by maps we may conclude that ageing is taking place in Europe in two dimensions: buttom-up ageing, and top-down ageing.

Bottom-up ageing, expressed as the proportion of 0-14 population, has become differentiated since the middle of the $20^{\text {th }}$ century among European countries (Figure 1). In this respect we can identify higher ratios of children in the countries of Eastern and Southern Europe; in contrast, a lower proportion is seen in Western European countries. In addition to the sharp decrease of this population group, its spatial pattern shows remarkable differences. In 2010 the lowest children ratios were seen in Germany (13\%) and Italy among European countries which were also front-runners in the mid-20 $0^{\text {th }}$ century. The liberalisation of the abortion law in 1972 (Coleman, D.A. 1993) contributed to robust bottom-up ageing in Germany, when both parts of the country saw a drop in total fertility rates down to 1.5. Ever since, the former West Germany has not been able to achieve higher levels. 


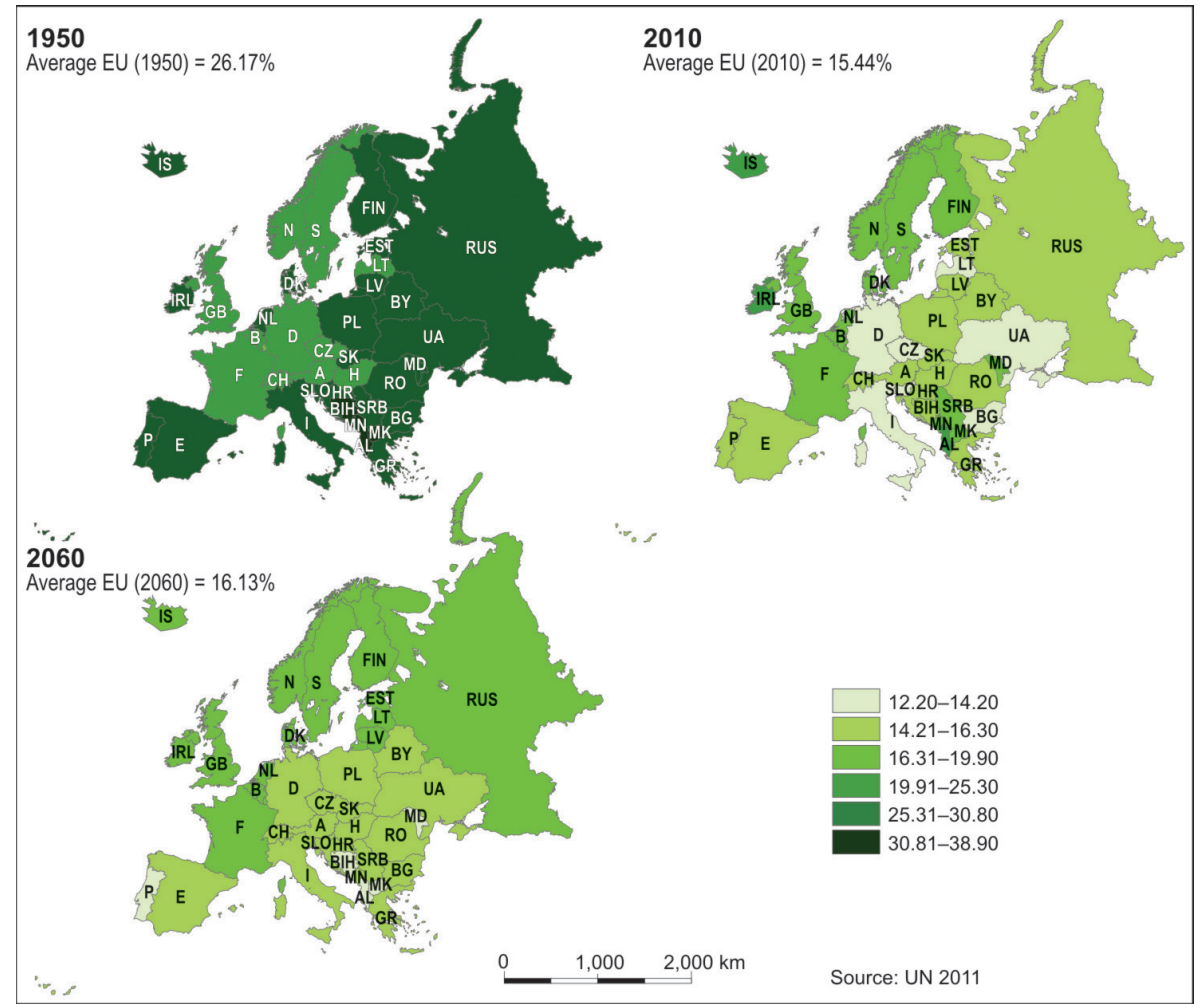

Fig. 1. Proportion of population aged 0-14 years in Europe, \%

However, minimum levels can also be seen in East Central European post-socialist countries e.g. Bulgaria, Slovak Republic, Czech Republic and Latvia. In this case, the main reason is a sharp drop in the birth rate as a result of a later start of the second demographic transition, multiplied by the complicated socio-economic situation (coupled with high unemployment rates) in the transformation period.

The position of Benelux countries is interesting within Europe, as these countries seem to be above-average throughout the monitored period. E.g. in the Netherlands a relatively late drop in fertility rate and a significant baby boom in the period immediately after WWII were the main reasons for continuing population growth (NIMWEGEN, N. et al. 2003). In Luxembourg population ageing is slower due to the massive immigration of younger age groups (Leduc, K. 2009). Long-term forecast shows an even starker bottomup ageing in the monitored countries. In spite of this fact we assume slightly 
better values in Northern and Western Europe in comparison with Eastern and Southern Europe. Bottom-up ageing will be fastest in countries which currently have higher proportions of children in the population (Albania, Macedonia and Moldova).

Top-down ageing expressed by the proportion of population aged 65+, shows a more radical development. The growth of the proportion of elderly generally spreads from the West to the East. The maximum values in 1950 were recorded in France, Latvia, Ireland, Belgium and Great Britain, i.e. countries where the first manifestations of the second demographic transition were seen after World War II (Figure 2).

Currently, on the basis of the elderly Europe can be divided into two parts: Western older one and the Eastern younger one. The reasons for this situation were identified in the work of Meslé, F. and Vallin, J. (2002). They pointed out that thanks to progress in the treatment of infectious diseases in the 1950s life expectancy in Eastern Europe increased to the levels of Western

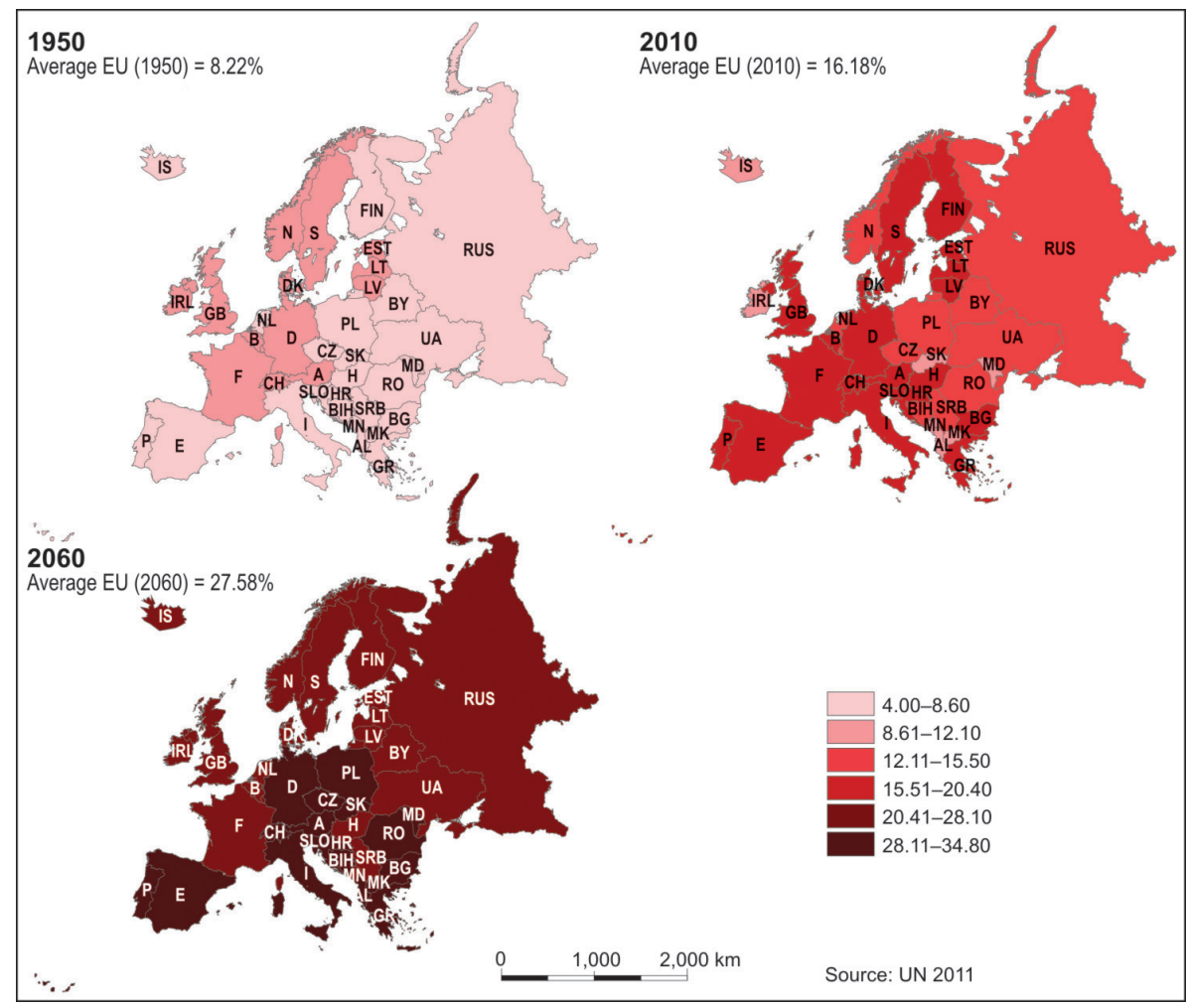

Fig. 2. Proportion of population aged 65 years and over in Europe, \% 
European countries. However, Western countries, after a slight stagnation in the 1960s, saw further progress in medicine, mainly in the area of treating cardio-vascular diseases, which Eastern European countries could not keep pace with, consequently their life expectancy started to stagnate or even fell. Cardio-vascular diseases belong to the most frequent causes of death of seniors (Holmerová, I. et al. 2007). The variation interval of this indicator $(8 \%-10 \%-$ $11 \%$ points) has a slightly growing tendency; the top-down ageing process is diversified in the European area. The populations of Germany and Italy are the oldest top-down ageing populations in the whole monitored period.

The development of fertility and mortality have special implications in the age structure of European countries. In many studies fertility is considered to be a decisive factor determining the process of population ageing (Dittgen, A. 1989; Bartoňoví, D. 2001; JaCkson, N. 2001). In the monitored period European countries have seen significantly lowering fertility rates. The group of European countries is very homogeneous in this respect; according to the forecast, in most countries it will remain just below the maintenance value. On the other hand mortality rates are improving, as indicated by the life expectancy values, even though the heterogeneity of the indicator is much stronger as in the case of fertility. Mortality rate is expected to differentiate population ageing in Europe in the future.

At the same time, we may also see a certain influence of migration on population ageing. "Currently, migration from so-called third world countries is becoming increasingly important, and most European countries have a positive migration balance; 24 out of $27 \mathrm{EU}$ countries. In absolute numbers, the highest migration increase was seen in 2005 in Spain $(652,000)$ and Italy $(338,000)$, followed by Great Britain $(196,000)$, France $(103,000)$ and Germany $(99,000)$. As for Central Europe, the highest migration increases are seen in the Czech Republic (36,000)" (Muez, R. 2007).

A triangle chart enables us to make a synthetic assessment of age structures within Europe, according to the representation of three productive population age groups (Ossan triangle). The sides of an equilateral triangle show the shares of three age groups, representing the coordinates of positions of individual countries in the chart. If we use average proportions of age groups in the whole Europe, then the chart is divided into six fields displaying individual types of age structures (Figure 3). The lines of averages enable us to classify countries into 'young' and 'old', while different averages of the representation of age categories in 1950, 2010 and 2060 have to be taken into consideration.

Table 2 shows the representation of individual types of age structures. The numbers of types in the three monitored years has to be assessed separately. The 'young' and 'old' populations have different parameters of representation of individual age categories. 


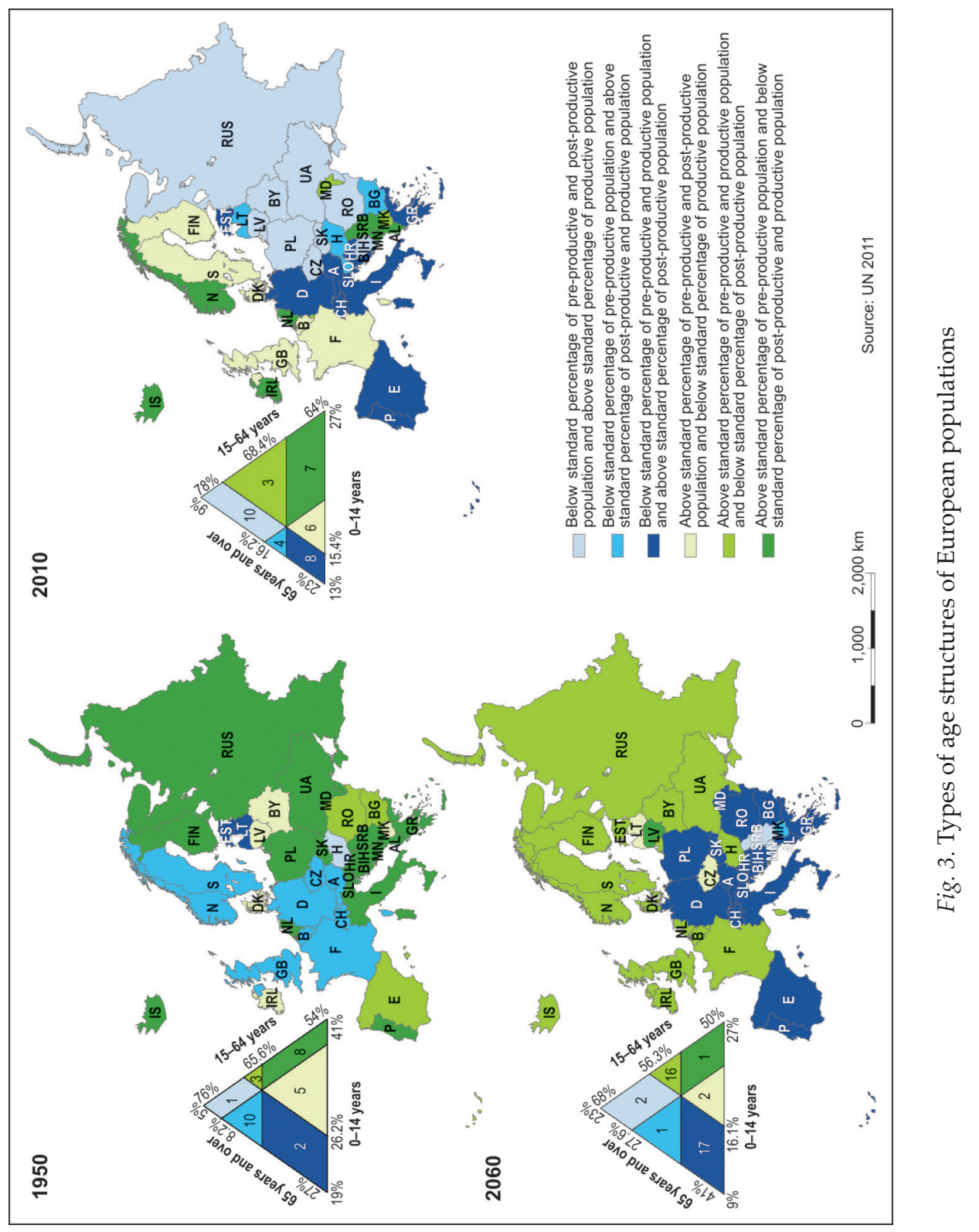


Table 2. Types of European populations according to age structures

\begin{tabular}{|c|c|c|c|c|c|c|}
\hline \multirow{3}{*}{$\begin{array}{l}\text { Types of population according to the } \\
\text { shares of age-groups (in comparsion } \\
\text { with average age structure of Europe) }\end{array}$} & \multicolumn{2}{|c|}{1950} & \multicolumn{2}{|c|}{2010} & \multicolumn{2}{|c|}{2060} \\
\hline & $0-14$ & $65+$ & $0-14$ & $65+$ & $0-14$ & $65+$ \\
\hline & \multicolumn{6}{|c|}{ number of states } \\
\hline young $^{*}$ & 26 & 22 & 16 & 20 & 19 & 19 \\
\hline old ${ }^{* *}$ & 13 & 17 & 23 & 19 & 20 & 20 \\
\hline \multicolumn{7}{|c|}{ according to both age groups } \\
\hline young & \multirow{3}{*}{\multicolumn{2}{|c|}{$\begin{array}{r}21 \\
12 \\
6\end{array}$}} & \multirow{2}{*}{\multicolumn{2}{|c|}{$\begin{array}{l}10 \\
13\end{array}$}} & \multicolumn{2}{|c|}{17} \\
\hline & & & & & & \\
\hline other & & & \multicolumn{2}{|c|}{16} & \multicolumn{2}{|c|}{4} \\
\hline
\end{tabular}

*Below standard percentage of $65+$, respectively above standard percentage 0-14.

${ }^{* *}$ Above standard percentage of $65+$, respectively below standard percentage $0-14$.

The assessment of countries applies to different average European proportions of populations of age groups. In 2010, Europe had 16 young populations, based on the proportion of people aged $0-14$, and 20 young populations, based on the proportion of people aged 65+. At the same time, there were 23 old populations, based on the proportion of people aged 0-14, and 19 old populations, based on the proportion of people aged 65+. If we combine both criteria, then there were 10 young and 13 old populations in Europe.

\section{Economic and social aspects of ageing in European countries}

The category of productive population is considered to be important from a socio-economic perspective. Its size depends both on young age groups joining the category of the productive population, or older age groups leaving it (Hrubý, J. 1996; Káčerová, M. 2009). The level and development of ageing has, therefore, significant impact on the size of the productive age group in each society. The ratio of population of productive age in Europe is currently $68 \%$. Since 1950 its number has increased by almost 29\%. The growth has been extremely influenced by two cohorts, people born in the 1950s and 1970s, i.e. the age category of 15-64 years, born in the last 60 years.

The size of the productive age group is currently culminating. 2011 represented the last year of an extreme growth of the productive age group, as it is considered to be the end of the effect of the post-war baby-boom cohort (Carone, G. and Costello, D. 2006). This generation will intensify and have a significant impact on the top-down ageing process after 2011. The forecast until 2060 assumes a decrease in the number of the productive age group by $27 \%$, meaning a level almost equal to that of 1950 (explained in more details by the inflow coefficient). An absolute expression of this age group in combination with an old or young population is defined by specific indicators. 


\section{Coefficient of inflow}

The coefficient of inflow $\left(C_{i}\right)$ expresses the number of people aged 10-14 $\left(P_{10-14}\right)$ joining the productive age group $\left(P_{15-64}\right)$ per 100 people in the productive age.

$$
C_{i}=\frac{P_{10-14}}{P_{15-64}} * 100
$$

In the base year of 1950, Europe was strongly differentiated according to the coefficient of inflow (Figure 4). The most favourable situation (above $17 \%$ ) could be seen on the Balkan, which was only in the initial stage of the demographic transition, and the total fertility rate was between 4.14 and 5.60 in many countries (Albania, Bosnia and Herzegovina, Macedonia), ensuring a stable influx of new labour force into the productive population category. Here Botev, N. (1990) also pointed out the possible influence of Islamic reli-

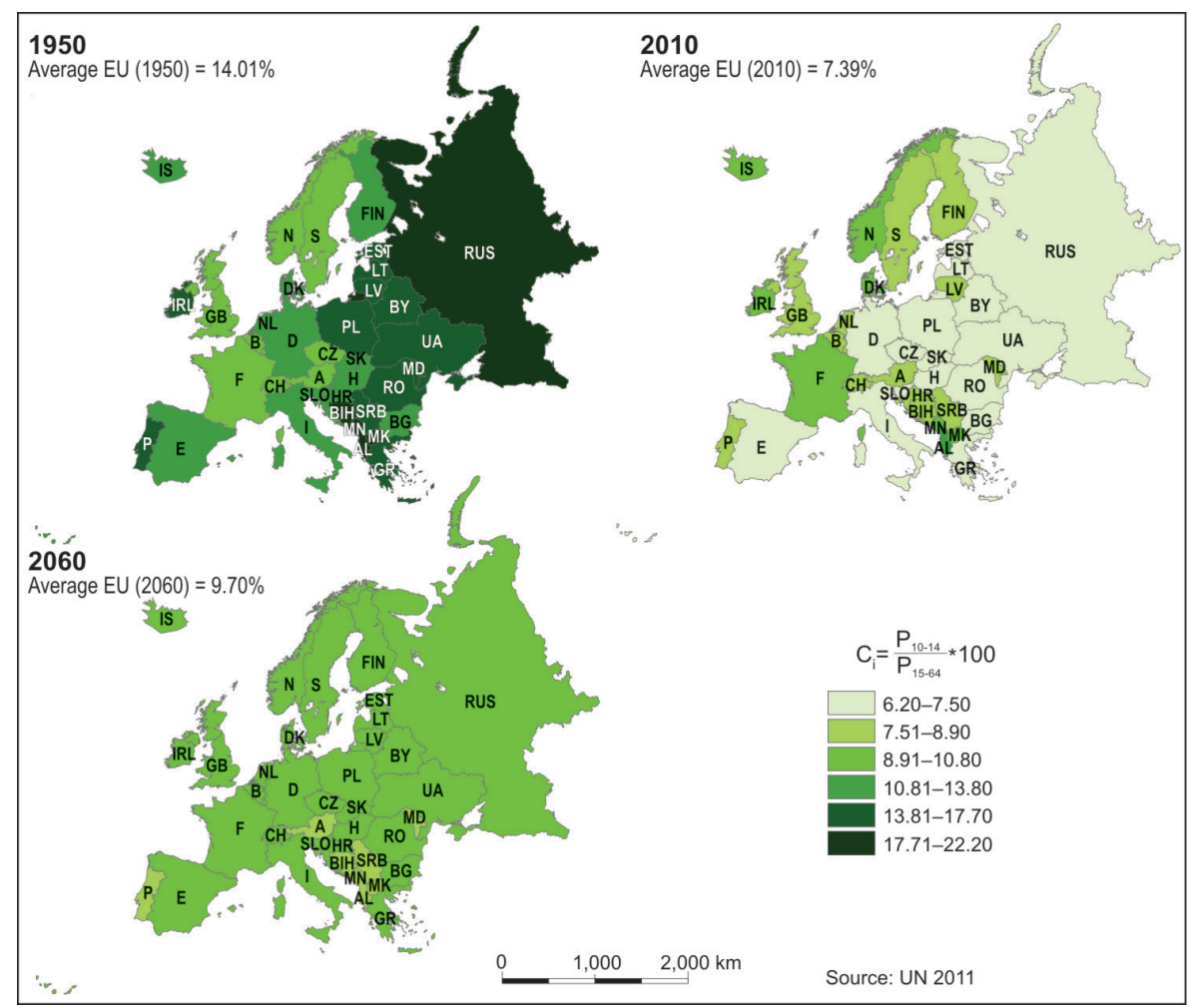

Fig. 4. Coefficient of inflow for European countries, \% 
gion on early marriages and higher fertility rates in some of these countries. Urbanisation played also a significant role which was only $20 \%$ in these countries in 1950, while in a number of Western and Northern European countries it was over 60\% (UN 1980). A similarly favourable situation in the inflow coefficient could be seen in Russia, where the age structure and mainly the representation of the productive age group was still considerably distorted by losses in World War II.

Below-average values of the coefficient $(7.51-13.80 \%)$ could be seen in Western and Northern Europe, which is connected with the division of Europe according to the Hajnal line. This area was characterised by a higher marriage age and consequently a lower number of children; and in Eastern Europe by a low marriage age and a higher number of children. After World War II some countries from the western model (e.g. the Czech Republic) approached the eastern model (RABUŠIC, R. 2001) and fertility was influenced by interferences and changes in regulations (pro-natality measures in Czechoslovakia in the 1970s, liberalisation of abortions in the 1950s and subsequent restrictions in the 1970s in most countries, etc.). At that time modern family planning was applied in Northern and Western Europe, leading to the second demographic transition in the 1970s. Natality was lower and people put off having children until a higher age. However, the subsequent births which were initially delayed partially erased this pace effect.

In Eastern Europe there was scope for spreading new demographic pattern in the 1990s, intensified by the complex socio-economic situation, including high unemployment rates and the inaccessibility of housing for young families. Thanks to these facts, 2010 saw higher values of the coefficient in Western European countries (above 8.91\%) in comparison with Eastern Europe (6.20-7.50\%). On aggregate, this indicator has dropped to half of its value since the mid-20 $0^{\text {th }}$ century. The forecast until 2060 assumes further growth and a certain unification of aggregate fertility in Europe. So in the future we can expect a levelling out in the spatial differentiation of the inflow coefficient.

\section{Coefficient of outflow}

The coefficient of outflow $\left(C_{o}\right)$ expresses the proportion of people aged 60-64 $\left(P_{60-64}\right)$ leaving the productive age group $\left(P_{15-64}\right)$ for the post-productive one.

$$
C_{o}=\frac{P_{60-64}}{P_{15-64}} * 100
$$

The group of people aged 60-64 leaving the labour market for retirement also plays a significant role in the number of productive age category. The 
coefficient of outflow inform us about this process, even though the age of retirement is specified by the law, and this is slightly lower in Eastern European countries (mainly for women) compared to the West. However, some trends are obvious. In the mid-20 $0^{\text {th }}$ century six people per 100 workers reached retirement age. Above-average values (above 6.71\%) were achieved in Western and Northern Europe mainly due to lower mortality rates (Figure 5).

As shown by Grundy, E. (1991), the cohort of people born between 1886 and 1900 was the very first in England and Wales where at least half the population lived until the age of 65 . There was a significant shift in this field until 2010, with the coefficient of outflow growing up to $8.28 \%$. The main reason was improving conditions in medicine (prevention, new medicines, technical and material equipment, accessibility of healthcare), thus also growing life expectancy. Currently all European countries have a higher life expectancy at birth than the age of 69 . Higher values of the coefficient (above $7.91 \%$ ) are again recorded in Western and Northern Europe. Here a more pronounced

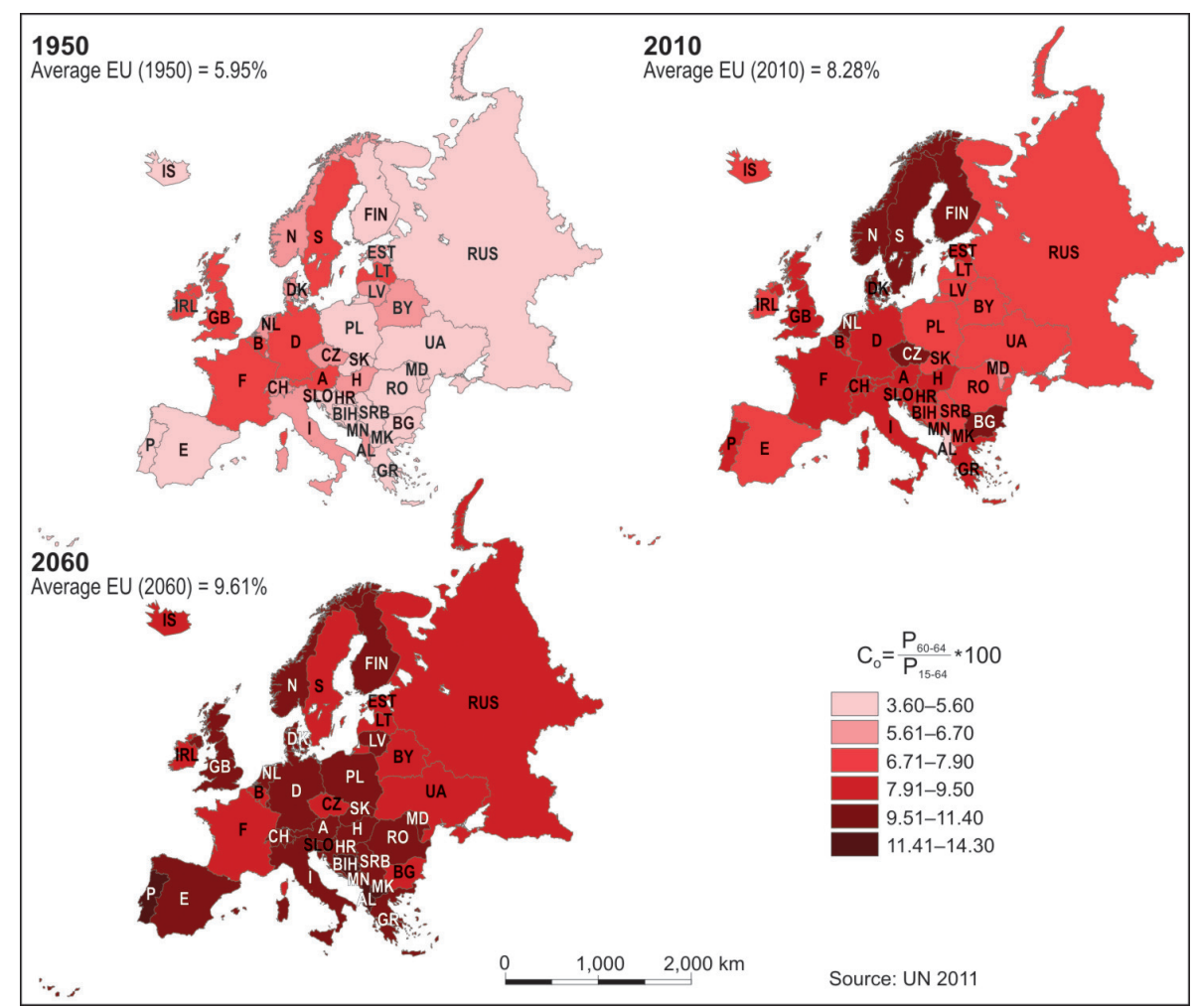

Fig. 5. Coefficient of outflow for European countries, \% 
post-war baby boom is also a contributing factor in comparison with Eastern Europe. However, spatial patterns will change in the future. Some countries with currently extreme values (e.g. Czech Republic, Sweden, Finland, Bulgaria) may even see a drop in the outflow coefficient. In contrast, the countries of the Balkan will have a rapidly ageing labour force (in particular Albania, Bosnia and Herzegovina and Macedonia).

\section{Coefficient of exchange}

The coefficient of exchange $\left(C_{e}\right)$ expresses changes in the proportion of people, entering' $\left(P_{10-14}\right)$ and ,leaving ${ }^{\prime}\left(P_{60-64}\right)$ the productive age category.

$$
C_{e} \frac{P_{10-14}}{P_{60-64}} * 100
$$

The most dynamic development is seen in the field of the coefficient of exchange (Figure 6). In the base year, much bigger generations entered the productive age group than were leaving in all European countries. Generally, Europe was characterised by the entry of 235 potential workers (aged 10-14) per 100 people leaving the productive age group (aged 60-64). On the one hand, highest values could be observed in Russia and in some Balkan countries where the exchange coefficient was over 345\% in 1950. On the other hand, lowest values (below 172.50\%) were recorded in North-Western Europe, in Germany, or in the Czech Republic that was more similar to Western than Eastern populations with its demographic behaviour in this period. Europe has considerably changed as a result of the drop in the inflow coefficient and the rise in the outflow coefficient since 1950.

In 2010, in many countries the entering age groups did not compensate the loss caused by people leaving the active age group, and the productive age group was shrinking. Countries were trying to deal with this challenge by using migration; however, as research has shown (UN 2001; Lutz, W. and SHerbov, S. 2003) its impact was not sufficient. Countries are currently focusing more on the migration of highly-qualified people. Nonetheless, their number may help avert a natural loss rather than bring about a change in the age structure.

Moreover, it is often illegal migration from third countries and the incorporation of migrants in the society is problematic. In this case we can also speak about a certain levelling out of values; more distinctive favourable values (above 114.21\%) have only remained in some Balkan states or Iceland and the markedly catholic Ireland. Similarly, balanced values are also assumed by the population forecast; however, it is only the area of the Balkan peninsula that will see the least favourable values (below $85.10 \%$ ). 


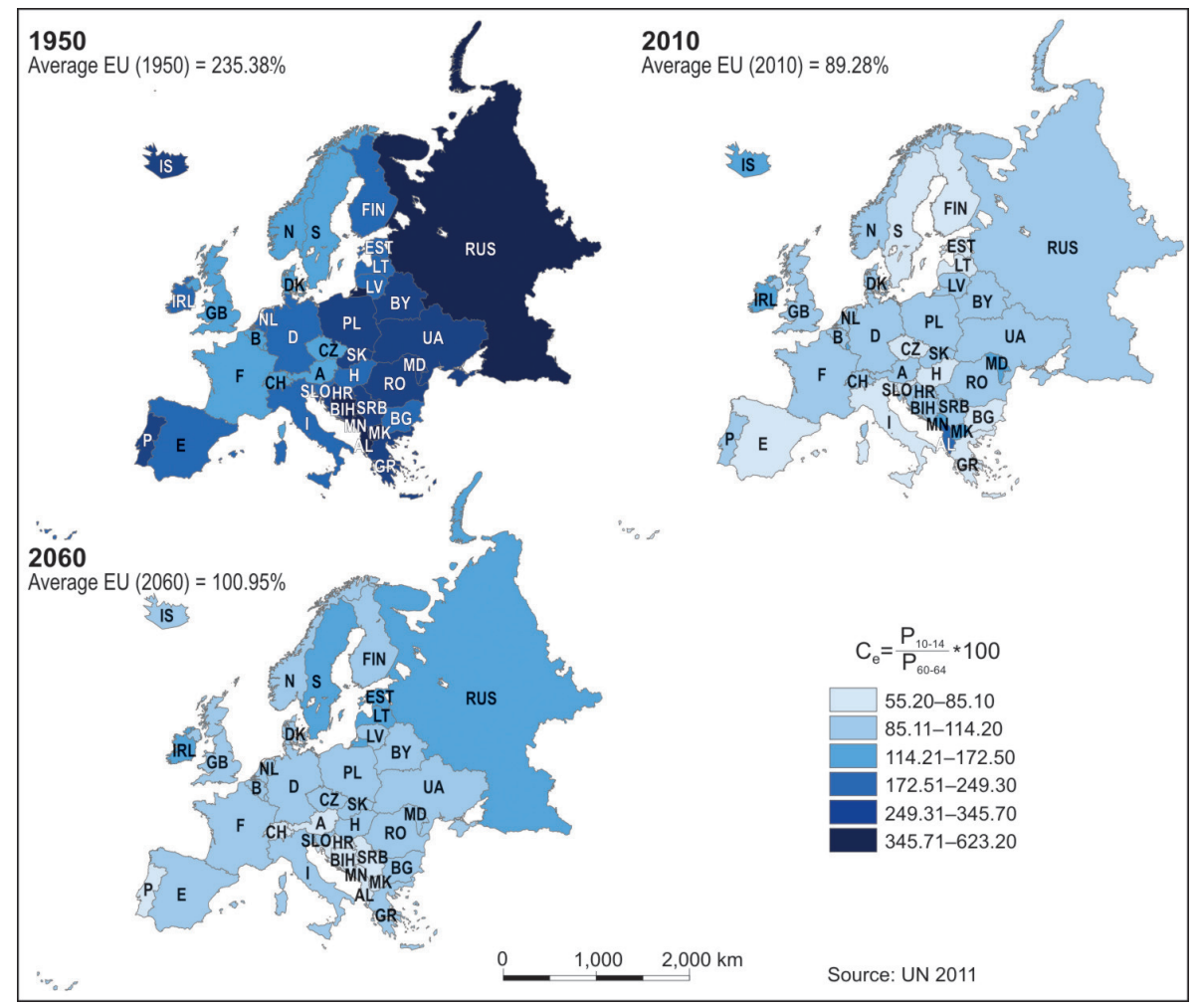

Fig. 6. Coefficient of exchange for European countries, \%

\section{Index of economic support}

The index of economic support $\left(I_{e s}\right)$ expresses the number of population in the productive age $\left(P_{15-64}\right)$ falling on 100 persons (or on 1 person) in the postproductive age $\left(P_{65+}\right)$.

$$
I_{e s}=\frac{P_{15-64}}{P_{65+}} * 100
$$

On the basis of the previous indicators the index of economic support can be elaborated (Figure 7). The value of the European average of this indicator is decreasing in the investigated period. The number of those working per seniors is radically changing. 1950 saw significant economic security, when almost 8 people of the productive age worked per one pensioner. More than 10 people of the productive age per one senior was recorded in Eastern Europe in 


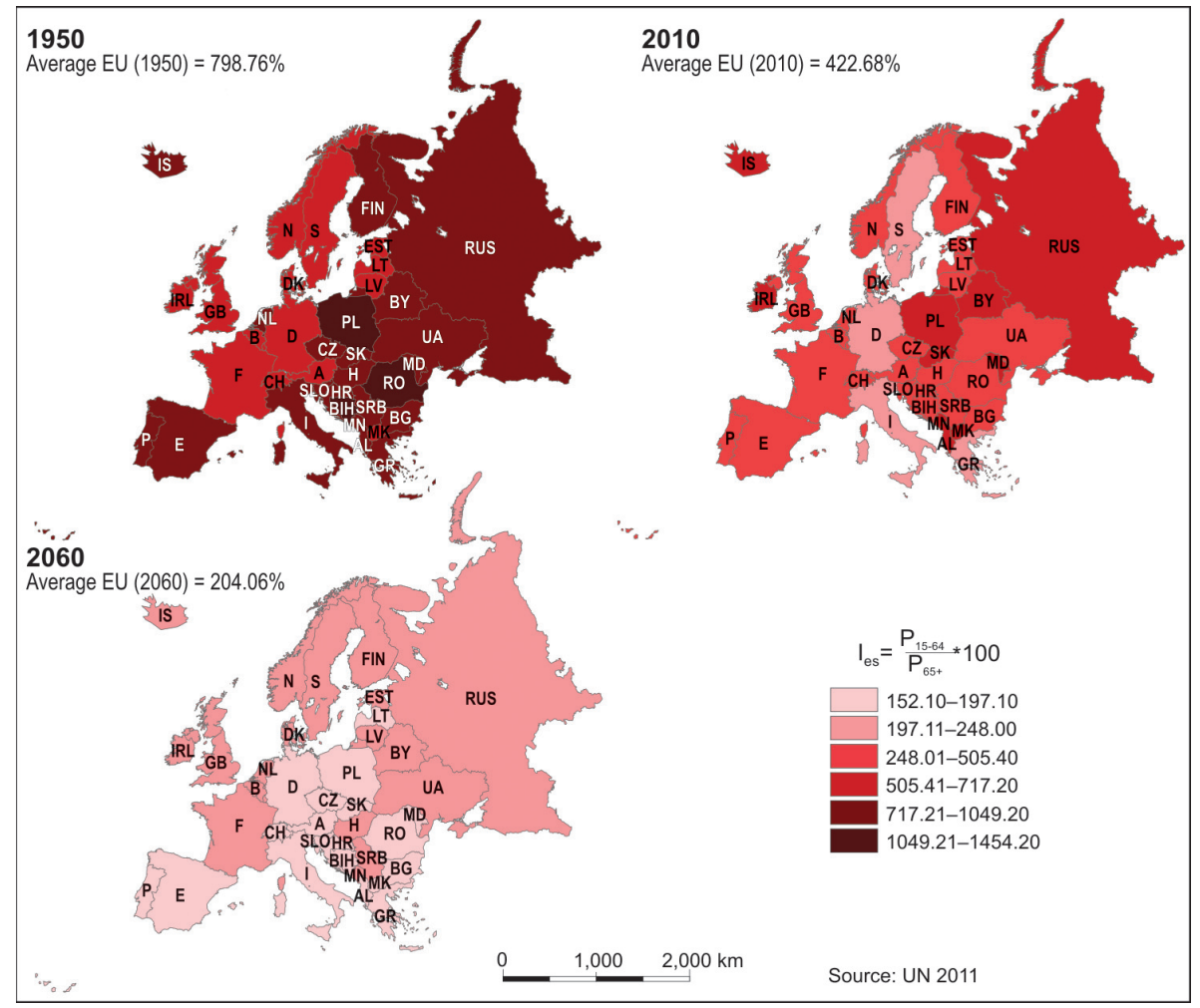

Fig. 7. Index of economic support for European countries, \%

the mid-20 $0^{\text {th }}$ century (the low proportion of the old population in these countries had a significant impact on this fact). Maximum values were achieved by Bosnia and Herzegovina, followed by Poland and Romania. Countries with a larger proportion of old population had lower economic support of elderly population (e.g. Ireland, France, Lithuania).

Until 2010, the spatial pattern has partially changed. E.g. thanks to migration gains, Ireland became a country with an above-average support value: 5.75 workers per pensioner. Although their population ageing process has become more distinctive in the last 20 years, Slovakia, Moldova and Albania are countries where the number of working people was higher than 6 per one senior. These are European maxima. The populations of Germany and Italy, being currently the oldest, have fewer than 3.3 working people per one senior. The situation until 2060 assumes that the oldest populations will retain their minimum positions and will be below the average. Yet countries of Southern Europe and the Balkan will achieve the lowest values. 


\section{Index of social support}

The index of social support $\left(I_{\mathrm{ss}}\right)$ expresses how many people aged 80+ $\left(P_{80+}\right)$ fall on 100 persons aged 50-64 $\left(P_{50-64}\right)$. This ratio may also be understood as a relation between generations of parents and their children and as a potential direct inter-generation help.

$$
I_{s s}=\frac{P_{80+}}{P_{50-64}} * 100
$$

The relation of 'parents' and their children, expressed through the index of social support in 1950 reflected the fact that the European average of the proportion of population aged $80+$ was $1.1 \%$ (Figure 8). People born in the $19^{\text {th }}$ century were not expected to live until old age and their numbers were influenced by migration waves and wars. In spite of that, the indicator shows great geographical differences.

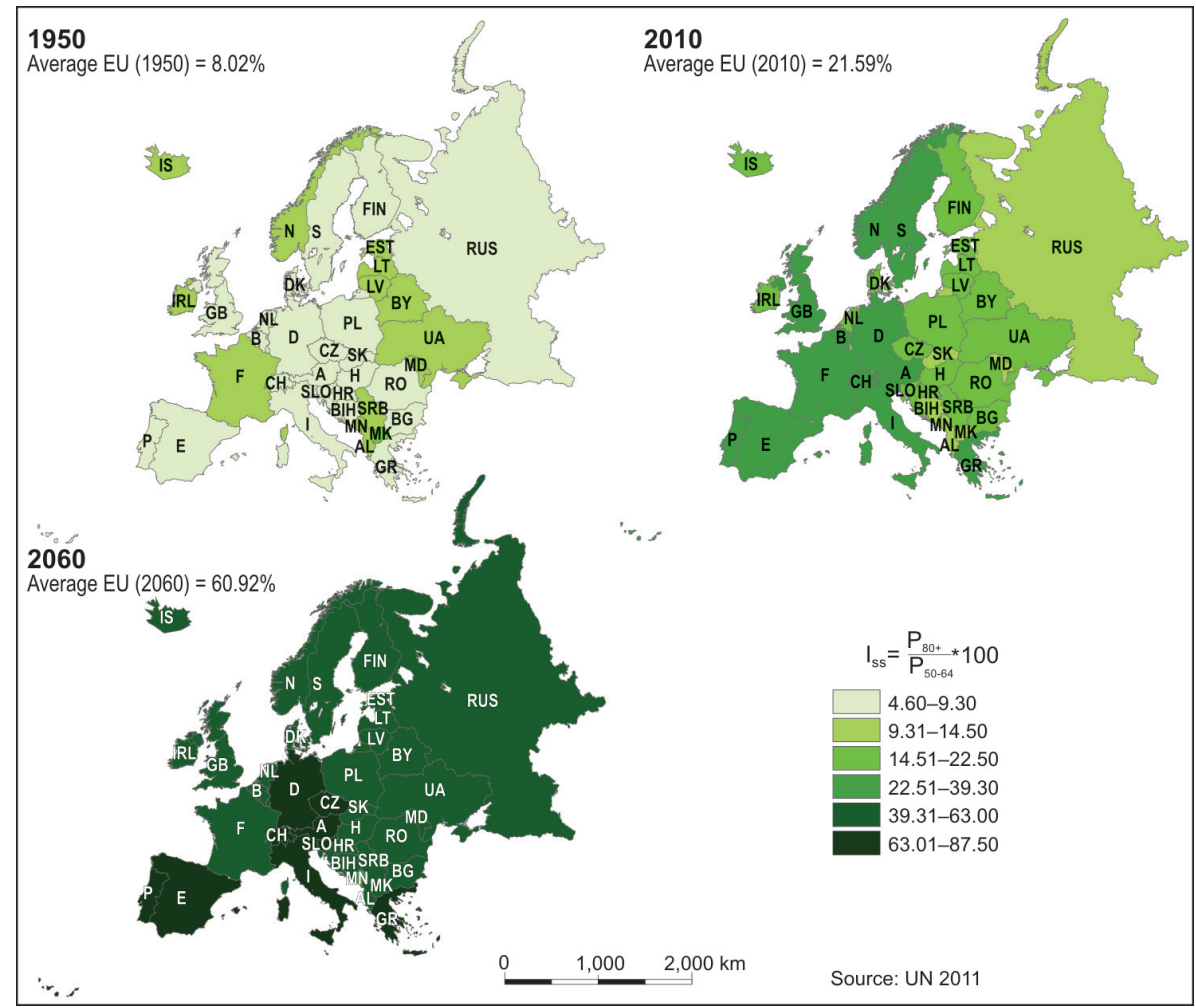

Fig. 8. Index of social support for European countries, \% 
A higher index of social support was seen in the Baltic countries where the share of population aged $80+$ was higher (1.5-1.8\%). Another group was formed by the Balkan countries which, on the contrary, had a significantly below-average representation of the productive age group (54-58\% in comparison with the European average of $66 \%$ ). The main reason could be the massive emigration of young people after 1990 in these countries and a low fertility rate (LuKIC, T. et al. 2012).

In 2010 the spatial differentiation reflected the level of population ageing (in particular the ageing of the senior population itself) and a spread of the second demographic transition: Eastern and Central Europe with a lower social support index value and Western and Northern Europe with a higher value. The Benelux countries and Ireland are exceptions; they are considered to be younger, thanks to migration. The projected period identifies the highest need for social support in Spain, Italy and Switzerland, where there are more than 80 seniors aged $80+$ per 100 people aged 50-64. In contrast, the lowest values are seen in Montenegro, Serbia, Russia, Moldova and Albania. A common factor in these countries is low life expectancy. A secondary factor in Moldova is the effect of migration. It started after 1990, and according to statistical data, 314,000 people emigrated, i.e. almost $10 \%$ of the population (Helpage International, 2010).

\section{Complex assessment of ageing of European populations}

The complex assessment of population ageing with several indicators offers detailed information on its evolution and regional differentiation. Sometimes the individual assessment of these indicators is misleading and the assessment of the population ageing may be ambiguous. Therefore, a synthesis of these indicators has become topical. On the level of European countries, this task was performed using the method of standardized variable. It is a method which transforms some real data (with different nature and sometimes unitsof measurement) for certain geographical units (countries) into comparable systems of measurement (non-dimensional figures), enabling to perform various statistical operations.

In our study eleven indicators of ageing or age structure were used for all European countries, including: population aged 0-14, Billeter index, inflow coefficient, exchange coefficient, index of economic support with a negative relation to population ageing, and $65+$ aged population, $80+$ aged population, ageing index, outflow coefficient, index of social support, age median with a positive relation to population ageing.

As a second step every indicator was changed by standardization into a non-dimensional figure $\left(z_{\mathrm{i}}\right)$ : 
If the relation to ageing is positive:

$$
z_{i}=\frac{X_{i j}-\bar{X}_{j}}{s_{x j}}
$$

If the relation is negative:

$$
z_{i}=\frac{\bar{X}_{j}-X_{i j}}{s_{x j}}
$$

where $X_{i j}$ is the indicator value for the particular country, $X_{j}$ is the indicator average and $s_{x j}$ is a standard deviation of the particular indicator.

The resulting characteristic - a synthetic indicator - was specified as a weighed arithmetic average of the standardised values:

$$
S_{i}=\frac{1}{k} \sum \frac{k}{1} z_{i j} \cdot v_{j}
$$

where $i=1,2 \ldots n ; v_{j}=$ weight of the $j^{\text {th }}$ indicator (in our case the weight for all indicators was equal to 1 ).

In view of the fact that we wanted to achieve comparability of values over time, the European average was calculated for all three periods. With a standard division, the value of the synthetic indicator achieves values in the interval from -3 to +3 (StAnkovičová, I. and Vojtкová, M. 2007).

The values of the indicator are directly proportional to the level of population ageing, with the oldest European populations achieving the highest values.

The synthetic analysis of population ageing shows considerable ageing in all European countries (Figure 9). The result of 1950 showed strong dichotomy within European with two distinct macro-regions from the point of view of current population ageing.

Countries of Southern and Eastern Europe were characterised by a population with the youngest (the Balkan, Russia, Poland) and very young age structure, whereas countries of North-Western Europe had a young age structure. In 1950, all 39 countries were in the three sub-types of young population. By 2010, only the population of 11 countries remained in the 'young population' type, and the rest moved to the other three types of old population.

The ageing of population in the individual countries and their shifts between the constructed types were not so simple or straightforward.

In the first period (1950-2010) Albania, Bosnia and Herzegovina, Montenegro, Russia, Iceland, Ireland, Romania, Slovakia, Moldova, Macedonia and Serbia were clearly presented as the youngest populations. Their young 


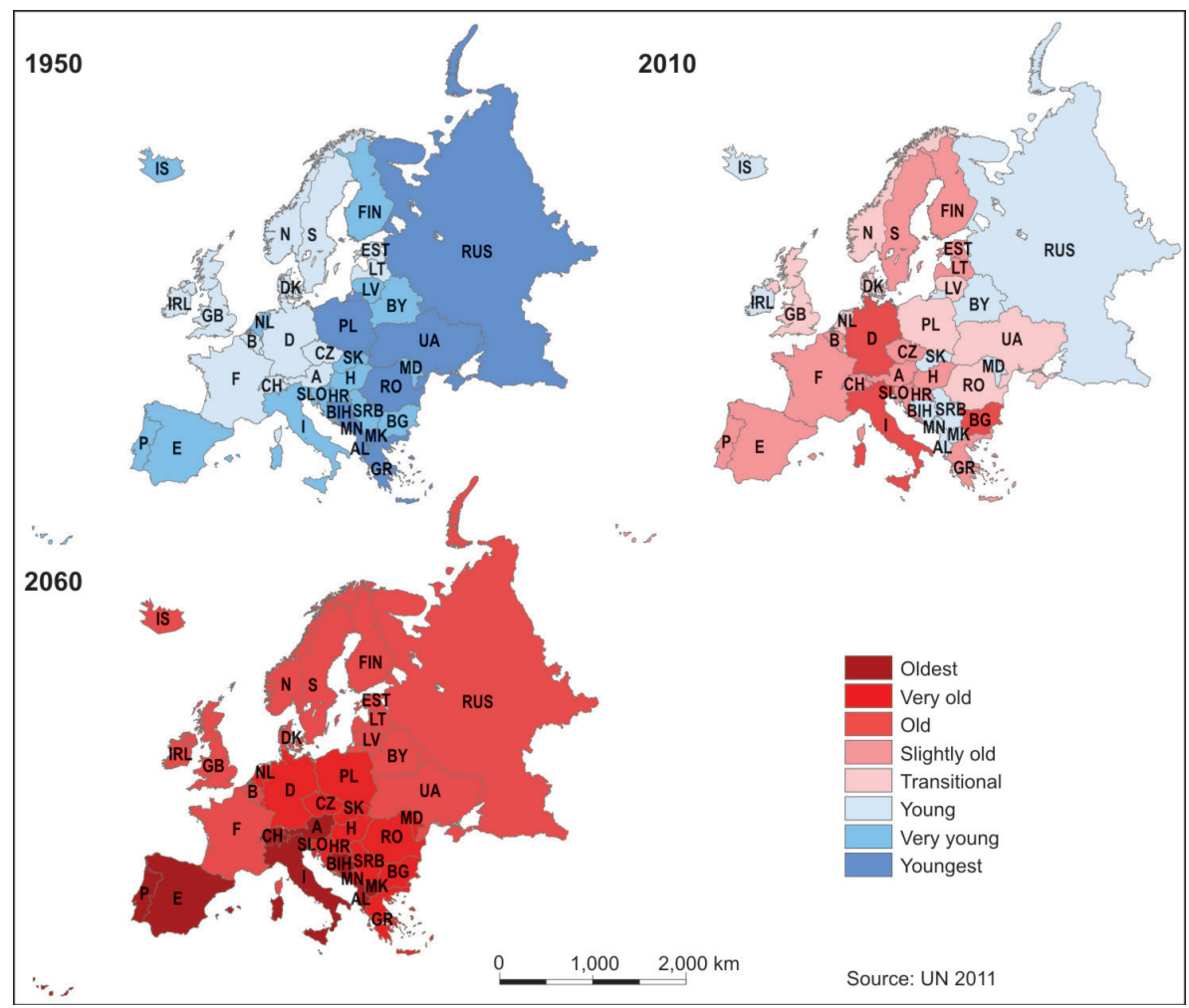

Fig. 9. Types of population according to intensity of population ageing in Europe

age structures were still influenced by a relatively higher fertility rate; the top-down ageing was manifested in a lower extent. On the other hand, the oldest populations were seen in Italy, Germany, Austria, Switzerland, Sweden, Belgium, France, Great Britain and the Czech Republic.

In this period, age structures were assessed on the basis of the real achieved values. Population ageing is expected to continue until 2060 to a certain extent (based on the projected values). Populations of all countries will shift to the three oldest types of population by then. In addition to traditional countries with old population, also Bosnia and Herzegovina, Albania, Portugal, Malta, Macedonia, Moldova and others will become countries with very old population. These countries will see the effect of a cyclical transition of numerous young generations (from 2010) to older age groups (top-down ageing). 


\section{Conclusions}

The demographic behaviour of the European population in the second half of the $20^{\text {th }}$ and the beginning of the $21^{\text {st }}$ century is characterised by significant changes. They are reflected in a number of population processes and structures, what are strongly interconnected. These changes have been most strikingly manifested in a drop of fertility, changes in family behaviour, and changes of population age structures. Changes in population age structures are mainly characterised by the processes of ageing (rejuvenation was only seen in shorter time periods), both from the bottom as well as from the top. Bottom-up ageing is a result of a radical drop in fertility (until 2010 the total fertility dropped below the replacement level in all European populations with the exception of Iceland and Ireland). This process is slowly coming to end, and until 2060 fertility should rise slightly, thus softening the bottom-up ageing processes.

Top-down ageing process has been influenced by two demographic and social phenomena. The first one was the fact that numerous generations entered the post-productive age (mainly from the period of high fertility after World War II). The second one is the extension of life expectancy as a result of increasing standard of living in many areas of material conditions, better healthcare, and a higher level of education.

A characteristic feature of age structures is their regional differentiation; and it is also true for the population of European countries.The ageing level in 1950 was distinctively differentiated, mainly as a result of extremely young and old populations. This differentiation decreased until 2010, and the group of European countries has become more homogenous. This trend of levelling out will continue, and in 2060 the differences in ageing will be significantly lower.

The processes of population ageing have relevant social and economic consequences; therefore large number of indicators and different methods should be applied to learn these processes. Indicators such as coefficients of inflow, outflow and exchange, have brought interesting results. The effort to make a synthetic assessment on the level of population ageing has become topical as well. Using the method of standardized variable, 11 partial indicators of age structures of 39 European countries have been used in the synthesis. In view of the large span of the assessed time period, a significant number of types of age structures have appeared in our typology.

In the first period (1950-2010) structures were assessed on the basis of real values, and in many countries they were presented quite clearly and unambiguously. Several countries in Western and Northern Europe have seen older age structures (earlier fertility decrease, longer life expectancy). In Central, Eastern and mainly Southern Europe younger age groups have been identified 
(higher fertility, lower life expectancy). Classification into individual types of age structures in the projected period has changed in many countries.

Acknowledgement: The paper was written within the project VEGA 1/0562/12 entitled „New demographic analyses and projections of population in Slovakia and its regions, using advanced geographical applications" and the project APVV-018-12 entitled "Human Geographical and Demographic Interactions, Nodes and Contradictions within TimeSpace Network."

\section{REFERENCES}

BARToŇOvá, D. 2001. Demografické chování populace České republiky v regionálním a evropském kontextu (Demographic behavior of population of Czech republic in the regional and European context). In Regionální vývoj: specifika české transformace, evropská integrace a obecná teorie Eds. Hampl, M. et al., Praha, Univerzita Karlova v Praze, 45-73.

Botev, N. 1990. Nuptiality in the Course of the Demographic Transition: The Experience of the Balkan Countries. Population Studies 44. (1): 107-126.

Carone, G. and Costello, D. 2006. Can Europe Afford to Grow Old? Finance and Development 43. (3): 8-31.

Coleman, D.A. 1993. Contrasting Age Structures of Western Europe and of Eastern Europe and the Former Soviet Union: Demographic Curiosity or Labor Resource? Population and Development Review 19. (3): 523-555.

Dittgen, A. 1989. Population ageing in France, past, present and future. The impact of fertility, mortality and migration. Acta Demographic 9. (2): 7-33.

Grundy, E. 1991. Ageing: Age-Related Change in Later Life. Population Studies 45. 133156.

Helpage International 2010. Staying behind: The effects migration on older people and children in Moldava. Chisinau, HelpAge International in Moldova, 42 p. Avaible at: http:// www.unicef.org/moldova/The_impact_of_migration_on_older_people_and_children_in_Moldova.pdf (Last access: 2013-05-19)

Holmerová, I., JurašKová, B. and Zıkmundová, K. 2007. Vybrané kapitoly z gerontologie (Selected topics from Gerontology). Praha, EV public relations, 144 p. Avaible at: http://www.geriatrie.cz/dokumenty/VybrKapZGerontologie.pdf (Last access: 201006-28)

Hrubú, J. 1996. Základy demografie pre manažéra na vidieku (Basic of demographie for the manager in rural area). Nitra, Acta operativo-economica, 103 p.

JACKSON, N. 2001. The policy-maker's guide to population ageing: key concepts and issues. Policy research paper 13. Canberra, University Tasmania: School of sociology and social work, $68 \mathrm{p}$.

KÁČERová, M. 2009. Casový a priestorový aspekt poznávania procesu populačného starnutia obyvatel'stva Slovenska (Temporal and spatial cognition aspect of the process of population aging in Slovakia). Dizertačná práca. Bratislava, Univerzita Komenského v Bratislave. $135 \mathrm{p}$.

LANZIERI, G. 2011. The greying of the baby boomers. Statistics in focus. Population and social conditions 23.12 p. Avaible at: http://epp.eurostat.ec.europa.eu/cache/ity_offpub/kssf-11-023/en/ks-sf-11-023-en.pdf (Last access: 2013-04-01) 
Leduc, K. 2009. Luxembourg and the ageing of its economicallay active population: From public policies to firms 'policies. 15 p. Avaible at: http://www.uclouvain.be/cps/ucl/doc/demo/ documents/Leduc.pdf (Last access: 2013-04-21)

Lukic, T., Stojsavlevic, R., Durdev, B., Nad, I. and Dercan, B. 2012. Depopulation in the Western Balkan countries. European Journal of Geography 3. (2): 6-23.

Lutz, W. and Sherbov, S. 2003. Can Immigration Compensate for Europe's Low Fertility?. Vienna, Vienna Institute of Demography, 16 p. Avaible at: http://www.oeaw.ac.at/vid/download/edrp_no1.pdf (Last access: 2013-04-21)

MacKellar, F. L. 2003. The predicament of Population Aging: A review Essay. Vienna Yearbook of Population Research 1. 73-99.

Meslé, F. and Vallin, J. 2002. Mortality in Europe: the Divergence Between East and West. Population (English Edition) 57. (1): 157-197.

MLÁDEK, J. 1998. Druhý demografický prechod a Slovensko (Second demographic transition and Slovakia). Acta Facultatis Studiorum Humanitatis et Naturae Universitatis Prešoviensis, Folia Geographica 30. (2): 42-52.

Muez, R. 2007. Ageing and Demographic Change in European Societies: Main Trends and Alternative Policy Options. Social Protection Discussion Paper No. 0703. 38 p. Avaible at: http://www.monitoringris.org/documents/tools_reg/agingdemochange.pdf (Last access: 2013-05-04)

Nimwegen, N., Esveldt, I. and Beets, G. 2003. Population Trends and Family Policies in the Netherlands. Journal of Population and Social Security (Population), Supplement to Volume 1. 27 p. Avaible at: http://www.ipss.go.jp/webj-ad/webjournal.files/population/2003_6/7.van.pdf (Last access: 2013-05-04)

PAstor, K. 1998, Druhá demografická revolúcia (Second demographic transition). In 30 rokov Slovenskej štatistickej a demografickej spoločnosti. Bratislava, Slovenská štatistická a demografická spoločnost', 34-36.

Population Reference Bureau 2011. World Population Data Sheet 2011. Avaible at: http://www. prb.org/pdf11/2011population-data-sheet_eng.pdf (Last access 2013-04-21)

Rabušıc, L. 2001. Kde ty všechny děti jsou? Porodnost v sociologické perspektivě (Where are the all children? Natality in sociological perspective). Praha, Sociologické nakladatelství (SLON), $265 \mathrm{p}$.

Stankovičová, I. and Vojtкová, M. 2007. Viacrozmerné štatistické metódy s aplikáciami (Multivariate statistical methods with applications). Bratislava, Iura Editon, $261 \mathrm{p}$.

UN 1980. United Nations, Department of International Economic and Social Affairs, 1980. Patterns of Urban and Rural Population Growth. New York, UN, 175 p. Avaible at: http:// esa.un.org/unup/Archive/wuparchives/studies/United $\% 20$ Nations $\% 20 \% 281980 \%$ 29\%20-\%20Patterns\%20of\%20Urban\%20and\%20Rural\%20Population\%20Growth. pdf (Last Access 2013-04-21)

UN 2001. United Nations, Department of International Economic and Social Affairs, 2001. Replacement Migration: Is It a Solution to Declining and Ageing Populations? New York, UN, 151 p. Avaible at: http://www.un.org/esa/population/publications/migration/ migration.htm (Last Access 2013-04-21)

UN 2011. United Nations, Department of International Economic and Social Affairs, 2011. World Population Prospects: The 2010 Revision, CD-ROM Edition. Avaible at: http://esa. un.org/unpd/wpp/Excel-Data/population.htm (Last Access 2013-01-04)

VAN DE KAA, D.J. 1987. Europe's second demographic transition. Population Bulletin 42. (1): 1-59. 


\title{
Hungary in Maps
}

\author{
Edited by \\ Károly Kocsis and Ferenc Schweitze R
}

\section{Geographical Research Institute Hungarian Academy of Sciences Budapest, 2009. 212 p.}

\begin{abstract}
'Hungary in Maps' is the latest volume in a series of atlases published by the Geographical Research Institute of the Hungarian Academy of Sciences. A unique publication, it combines the best features of the books and atlases that have been published in Hungary during the last decades. This work provides a clear, masterly and comprehensive overview of present-day Hungary by a distinguished team of contributors, presenting the results of research in the fields of geography, demography, economics, history, geophysics, geology, hydrology, meteorology, pedology and other earth sciences. The 172 lavish, full-colour maps and diagrams, along with 52 tables are complemented by clear, authoritative explanatory notes, revealing a fresh perspective on the anatomy of modern day Hungary. Although the emphasis is largely placed on contemporary Hungary, important sections are devoted to the historical development of the
\end{abstract} natural and human environment as well.

In its concentration and focus, this atlas was intended to act as Hungary's 'business card', as the country's résumé, to serve as an information resource for the sophisticated general reader and to inform the international scientific community about the foremost challenges facing Hungary today, both in a European context and on a global scale. Examples of such intriguing topics are: stability and change in the ethnic and state territory, natural hazards, earthquakes, urgent flood control and water management tasks, land degradation, the state of nature conservation, international environmental conflicts, the general population decline, ageing, the increase in unemployment, the Roma population at home and the situation of Hungarian minorities abroad, new trends in urban development,

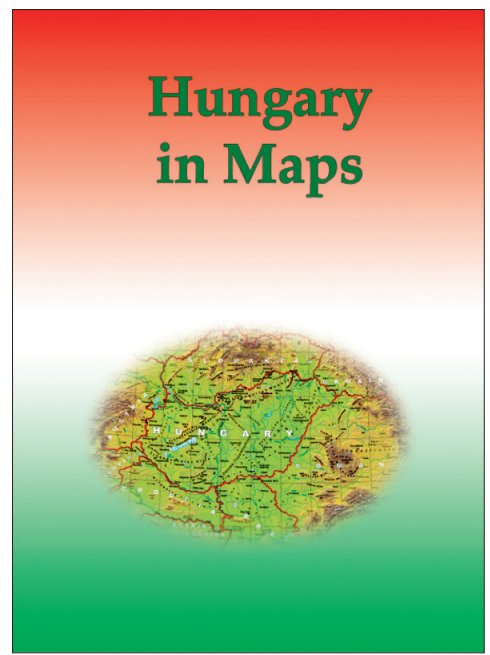
controversial economic and social consequences as a result of the transition to a market economy, privatisation, the massive influx of foreign direct investment, perspectives on the exploitation of mineral resources, problems in the energy supply and electricity generation, increasing spatial concentration focused on Budapest in the field of services (e.g. in banking, retail, transport and telecommunications networks), and finally the shaping of an internationally competitive tourism industry, thus making Hungary more attractive to visit.

This project serves as a preliminary study for the new, 3rd edition of the National Atlas of Hungary, that is to be co-ordinated by the Geographical Research Institute of the Hungarian Academy of Sciences. 